Brown, A. M. (1958). J. gen. Microbiol. 18, 48-57

\title{
Intracerebral Infection of Mice with Haemophilus pertussis and Passive Protection by Hyperimmune Rabbit Sera
}

\author{
By ANNIE M. BROWN
}

\author{
Serum Laboratory, Medical Research Council Laboratories, Carshalton, Surrey
}

\begin{abstract}
SUMMARY: The intracerebral invasion in mice by two Haemophilus (Bordetella) pertussis strains, a virulent strain and the strain 18-323 which is very virulent on intracerebral injection, was studied. The LD50 of these strains differed by about a thousand times and the average slopes of the regression lines from which these were calculated differed significantly, $(P=0.04$ and $P=0.01)$. It was found that the number of organisms/mouse brain in infected animals reached a maximum count which was slightly higher for the more virulent strain. The day on which the maximum count was reached depended both on the dose of organisms and the strain used, but occurred always before the seventh day after injection. Further, a slightly lower maximum count was reached as the dose of organisms was decreased. The passive protection by rabbit sera, described as antibacterial and antitoxic sera, against both these strains of pertussis organisms, was studied. It was shown that the protection of neither type of serum was due only to the presence of agglutinin antibodies.
\end{abstract}

The intracerebral infection of mice (Norton \& Dingle, 1935) in preference to the intranasal instillation (Burnet \& Timmins, 1937) was used by Ospeck \& Roberts in 1944 with virulent Haemophilus (Bordetella) pertussis organisms because of its precision in administration. By this method they challenged the passive protection conferred by hyperimmune rabbit sera in mice. Kendrick, Eldering, Dixon \& Misner (1947) described a strain of Haemophilus pertussis, 18-323, which was very virulent to mice by the intracerebral route. Small doses of this strain were used to challenge mice actively immunized with different doses of vaccines. Further work which was published in 1949 by Kendrick, Updyke \& Eldering led to the current method for the standardization of pertussis vaccines (M.R.C. Report 1956). Invasion of mouse brain by the organism was not extensively studied by any of these workers; it has now been investigated by using a virulent pertussis strain and the virulent strain 18-823.

\section{METHODS}

Strains of Haemophilus pertussis used. Two strains of pertussis organisms were used for the study of intracerebral invasion in mice and as challenge organisms against passive immunity in mice. The first strain, a smooth virulent freshly isolated one (no. 1011) which had been kept in the dried state, was obtained from the National Collection of Type Cultures; the second was the smooth virulent strain described by Kendrick et al. (1947) and was obtained from two sources and numbered, respectively, 1016 and 1017.

Experimental animals. Male Swiss breed mice weighing between 17 and $20 \mathrm{~g}$. were used for all experiments. Albino guinea pigs weighing not more 
than $350 \mathrm{~g}$. were used for the intracutaneous testing of pertussis toxins and antitoxins. Rabbits weighing between 2 and $4 \mathrm{~kg}$. were used for the production of hyperimmune antisera.

Antigens used to prepare hyperimmune sera. Vaccines containing approximately 10,000 killed smooth pertussis organisms $/ \mathrm{ml}$. were used as antigens in the production of antibacterial sera.

Toxic filtrates from the growth of smooth pertussis organisms in a meat infusion made with a plain papain digest of horse muscle (Linggood \& Fenton, 1947) containing $0.25 \%$ starch, similar toxic filtrates with the addition of $0.4 \%(\mathrm{w} / \mathrm{v})$ potash alum, and toxic extracts of organisms similarly grown, as prepared by Evans \& Maitland (1937), were used in the production of antitoxic sera.

\section{Preparation of hyperimmune sera}

Antibacterial sera. Group 1: up to ten graded doses of vaccine from $\mathbf{0} \cdot \mathbf{1}$ to $1.0 \mathrm{ml} . / \mathrm{kg}$. rabbit were given to rabbits by the intramuscular route at 2 -day intervals, with a rest of 1 month after the first two doses. Group 2: at least two courses of ten graded doses as above were given to rabbits, either intramuscularly or intravenously. The rabbits from both groups were bled on the fourth day or on the fourth and seventh days after injections. The blood serum obtained was clarified by rapid centrifugation or by sterilization through seitz EK filter pads.

Antitoxic sera. Rabbits were given by the intramuscular route graded doses of toxic filtrates, toxic filtrates with alum or toxic extracts, until the antitoxic potency of their blood serum ceased to increase. It was shown by Roberts \& Ospeck (1944) that antitoxic sera prepared against toxic filtrates from pertussis organisms neutralized the toxicity of toxic extracts from these organisms. Before use in protection experiments the blood sera from the fully immunized rabbits were absorbed with suspensions of smooth living pertussis organisms containing at least 20,000 million organisms $/ \mathrm{ml}$. After absorption the sera were heated at $56^{\circ}$ for $2 \mathrm{hr}$. held at $4^{\circ}$ for at least $24 \mathrm{hr}$., and finally clarified by centrifugation or filtration through Seitz pads. When the agglutinin titre had not been decreased to 100 or less by one absorption the process was repeated.

\section{Standardization of materials}

Preparation of suspensions and estimation of their total number of organisms. All cultures were kept in the dried state and were recovered by incubation at $37^{\circ}$ for $48 \mathrm{hr}$. and a further subculture for $24 \mathrm{hr}$, all on $50 \%(\mathrm{v} / \mathrm{v})$ sheep blood Bordet-Gengou medium. Suspensions made from organisms in Casamino acid broth (Cohen \& Wheeler, 1946) were standardized by visual comparison with a modification of the scale of opacities suggested by Brown \& Kirwan (1915). The suspension equivalent in opacity to opacity 4 on this scale was designated the standard suspension. It was found to contain approximately $8 \times 10^{9}$ organisms $/ \mathrm{ml}$. when counted in a Thoma bacterial counting cell.

Determination of the LD50 of each strain. The stability of each strain was 
checked at intervals throughout the work by the determination of its LD50 when injected in $0.05 \mathrm{ml}$. by the intracerebral route. Groups of 10 mice for each test dose of culture were observed during 21 days after injection. The results were calculated by the method of Reed \& Muench (1938).

Plate counts of pertussis organisms. Comparisons of the approximate number of live organisms in suspensions were made by the method of Miles \& Misra (1938). Bordet-Gengou sheep-blood medium containing 1 unit penicillin $/ \mathrm{ml}$. in plates of at least half a centimetre in thickness was used for growth of the organisms. Tests with organisms from a number of dryings of both strains showed that in comparisons made at different times the maximum number of organisms counted in one ml. of a standard suspension was $4.9 \times 10^{9}$ and the minimum $1.2 \times 10^{9}$. From the total estimated number of $8 \times 10^{9}$ organisms $/ \mathrm{ml}$. of standard suspension it may be deduced that between 15 and $60 \%$ of these organisms were viable.

Potency of antibacterial sera. The agglutinin titres were measured by using suspensions of live pertussis organisms and incubating the mixtures of serum and culture at $37^{\circ}$ overnight. Each serum when tested for the presence of antitoxin was found to contain less than one unit/ml.

Potency of antitoxic sera. The antitoxic titres of these sera were estimated by comparison with a serum standardized according to the unit of antitoxin defined by Roberts \& Ospeck (1944). In neutralization experiments any excess toxin present in a series of toxin-antitoxin mixtures could be indicated by death in mice, or by necrosis in rabbit skin (Roberts \& Ospeck, 1944) or by necrosis in guinea-pig skin. The latter method was chosen in this work. Guinea pigs with very thin skins were rejected as poor reactors. A scale in which the volume of each dose differed from the next by $20 \%$ was used for the serum dosage. Sera standardized in this way were known to contain antibodies other than antitoxin as they were prepared against impure antigens.

\section{RESULTS}

Comparisons of the relationship between the intracerebral dose in mice of virulent pertussis strain 1011 or of the virulent pertussis strain 1017 and the mortality of the mice injected

Similar suspensions of each of the above strains of pertussis organisms were made from organisms recovered from the dried state at the same time and subcultured on the same batch of Bordet-Gengou medium. Ten or 20 mice from one population of animals were injected intracerebrally for each of at least five doses of suspension. The animals were kept in the same part of the mouse room and observed for 21 days. Four comparisons were made in this way and the results are given in Table 1 . The slopes of the regression lines (Bliss, 1935) were determined by the method of Fisher \& Yates (1949) and the LD50 of each strain were calculated from the regression lines. The LD 50 found in this way agree with the values around 400 organisms for strains 1016 and 1017 and $200 \times 10^{3}$ organisms for strain 1011, determined 
at intervals during the work by the method of Reed \& Muench (1938). In the hope of finding another strain characteristic, the differences in the slopes of the regression lines for the two strains were compared for their significance with their standard errors by means of $t$-tests. The results (giving respectively a percentage possibility of similarity of slope of $58,50,55$ and 50) show that there was no significant difference between them when each experiment was analysed separately. However, in a block analysis, using the

\section{Table 1. Variance of mortality in mice from a series of doses of pertussis strains 1011 and 1017 injected intracerebrally}

Doses expressed as estimated total number of organisms. The slopes of the regression lines, and their standard errors, also the LD 50, were determined for each experiment.

\begin{tabular}{|c|c|c|c|c|c|}
\hline \multicolumn{2}{|c|}{$\begin{array}{l}\text { Expt. } \\
\text { Dose of organisms }\end{array}$} & \multicolumn{2}{|c|}{$\operatorname{Dead} / 10 *$} & \multicolumn{2}{|c|}{ Dead/20 } \\
\hline \multicolumn{2}{|c|}{$2 \times 10^{2}$} & - & - & o & 2 \\
\hline & $10^{3}$ & 2 & 1 & 4 & 0 \\
\hline Strain & $10^{4}$ & 2 & 3 & 5 & 6 \\
\hline \multirow[t]{3}{*}{1011} & $10^{5}$ & 5 & 4 & 6 & 17 \\
\hline & $10^{6}$ & 10 & 6 & 14 & 20 \\
\hline & $10^{7}$ & 9 & 9 & 20 & 20 \\
\hline \multicolumn{2}{|c|}{ LD 50} & $\begin{array}{c}96 \times 10^{3} \\
0.668 \pm 0 \cdot 416\end{array}$ & $\begin{array}{c}400 \times 10^{3} \\
0 \cdot 388 \pm 0 \cdot 278\end{array}$ & $\begin{array}{c}320 \times 10^{3} \\
0.628 \pm 0.329\end{array}$ & $\begin{array}{c}32 \times 10^{8} \\
0.982 \pm 0.542\end{array}$ \\
\hline & & \multicolumn{2}{|c|}{ Dead $/ 10$} & \multicolumn{2}{|c|}{ Dead/20 } \\
\hline \multicolumn{2}{|c|}{$4 \times 1$} & - & - & 1 & 0 \\
\hline \multirow{5}{*}{$\begin{array}{c}\text { Strain } \\
1017\end{array}$} & 10 & 1 & 2 & 1 & 8 \\
\hline & $10^{2}$ & 8 & 9 & 6 & 16 \\
\hline & $10^{3}$ & 9 & 9 & 18 & 20 \\
\hline & $10^{4}$ & 9 & 9 & 19 & 19 \\
\hline & $10^{5}$ & 8 & 10 & 20 & 20 \\
\hline \multicolumn{2}{|c|}{$\begin{array}{l}\text { LD50 } \\
\text { Slopes of line }\end{array}$} & $\begin{array}{c}200 \\
1.251 \pm 0.998\end{array}$ & $\begin{array}{c}200 \\
0.846 \pm 0.576\end{array}$ & $\begin{array}{c}504 \\
1 \cdot 026 \pm 0 \cdot 539\end{array}$ & $\begin{array}{c}104 \\
1 \cdot 446 \pm 0 \cdot 352\end{array}$ \\
\hline
\end{tabular}

* Figures are dead mice/group of 10 or/group of 20.

mean slopes of the lines, it was found that a $t$-test comparing the difference between the mean slopes of strains 1011 and 1017 with the standard error of this difference gave a significant result $P=0.04$, indicating that in only $4 \%$ of trials would the mean slopes be alike. Finally, when the hypothesis that there is no real difference between the slopes of the corresponding lines is considered, the mean difference between the slopes of the lines found for the two cultures when examined on the same day in the same population of mice should be zero. The $t$-test comparing the mean differences with the standard error of the mean difference gave the result $P=c .0 .01$ indicating that only in $1 \%$ of trials the results could be zero. This confirmed that the average slopes differed significantly, and established that the slopes of the regression lines determined as above are strain characteristics. As a matter of interest similar comparisons were made on two occasions by instilling the two strains intranasally. An average LD50 of $600 \times 10^{4}$ organisms for strain 1017 and 
of $200 \times 10^{3}$ organisms for strain 1011 indicated that by this route strain 1011 was slightly more lethal than strain 1017 . The slope of the regression lines determined by the method of Fisher \& Yates (1949) were such that in 86 to $>90 \%$ of trials these would be the same. Further analysis was unnecessary.

\section{The intracerebral invasion in mice with organisms from strains 1011 and 1017}

A series of experiments with each strain was arranged so that similar suspensions of organisms were injected intracerebrally into mice from the same population on one day. Thus on one day two groups of mice would receive respectively $0.05 \mathrm{ml}$. standard opacity suspension of strains 1017 and 1011 , while on a second day two groups would receive a suspension of $1 / 10$ standard opacity of these strains. In all, suspensions decreasing from standard opacity to standard opacity $\times 10^{-9}$ were tested. Groups of 30 to 75 mice were injected with each dilution of culture used to provide sufficient animals for a selection of four live animals from each group at intervals after injection. The day on which, owing to the deaths of animals, the selection ceased to be a random one, was noted for each dose of culture. All mice damaged by injection were discarded on the first day. Mice used for counts of pertussis organisms in the brain were killed with coal gas and their brains removed aseptically and disintegrated by the method used by Proom (1947) for the lungs of mice. Up to five dilutions of the original brain suspensions were used for plate counts by the method of Miles \& Misra (1938). Each plate was used for counts on two mice and each count was made in duplicate so that four plates were used for four mice. Differences in the numbers of viable organisms injected in each dose are reflected in the $1 \mathrm{hr}$. counts of the strains. These were due to the different challenge suspensions and the percentage of viable organisms in these different suspensions. The growth of the organisms from the two strains is compared in Figs. I and 2. The differences in the rates of growth and maximum numbers may be due to a fundamental difference in the metabolic requirements of these organisms. The falling off of the number of organisms after the third or fourth day with strain 1011 and the decrease in the maximum count reached after this time with strain 1017 may be due to phagocytosis. The shape of the curves will be determined by the balance between growth and removal of the organisms, and is characteristic for each strain.

\section{The protection by antibacterial and absorbed antitoxic sera against lethal intracerebral doses of pertussis strains 1011 and 1017}

Intraperitoneal graded doses of sera were given $24 \mathrm{hr}$. before intracerebral challenge with culture. In each series of protection experiments against any particular dose of culture, the numbers of mice/dose of serum were equal and varied from 5 to 30 mice/serum dose according to the volume of serum available. The protective dose of serum giving $50 \%$ end-points (PD 50) were calculated for each challenge dose of culture by the method of Reed \& Muench. Results are given for three antibacterial sera and three absorbed antitoxic sera 


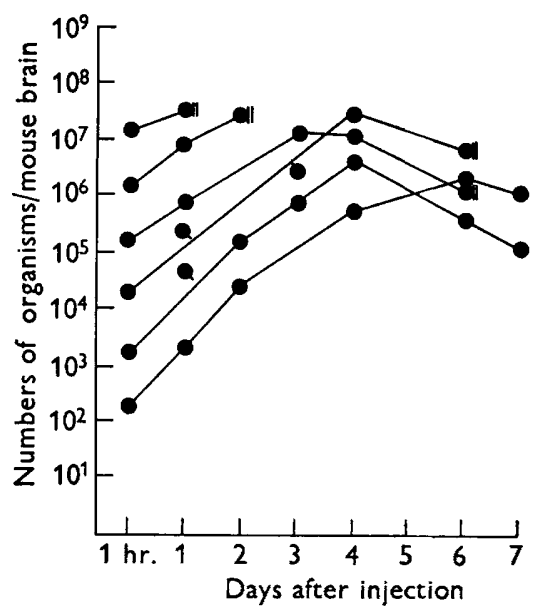

Fig. 1

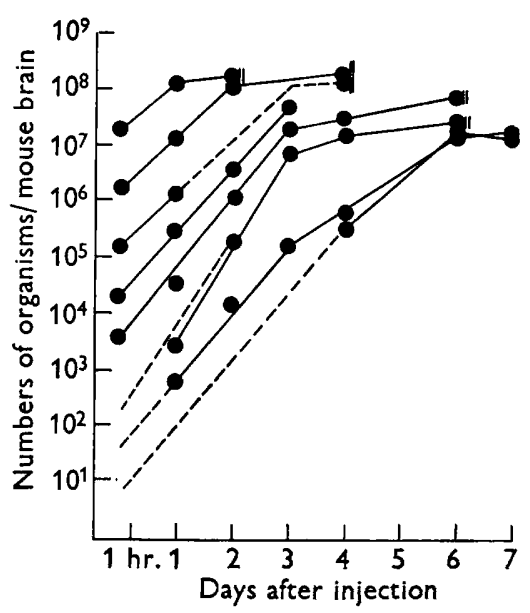

Fig. 2

Fig. 1. Average counts of pertussis organisms recovered from mouse brain after intracerebral doses of strain 1011. II Indicates first day on which deaths of mice occurred.

Fig. 2. Average counts of pertussis organisms recovered from mouse brain after intracerebral doses of strain 1017. II Indicates first day on which deaths of mice occurred. ----, Direction of graphs deduced by comparison with others of the series.

Table 2. Fifty \% end-points of protection with antibacterial and absorbed antitoxic sera against intracerebral challenge doses of pertussis strains 1017 and 1011.

\begin{tabular}{|c|c|c|c|c|c|c|c|c|}
\hline \multirow[b]{3}{*}{$\begin{array}{l}\text { Antibacterial } \\
\text { serum }\end{array}$} & \multirow{3}{*}{$\begin{array}{c}\text { No. } \\
\text { mice/ } \\
\text { serum } \\
\text { dose }\end{array}$} & \multicolumn{5}{|c|}{$\begin{array}{l}\text { Strain } 1017 \\
\quad \text { Challenge } \times \text { LD } 50\end{array}$} & \multicolumn{2}{|c|}{ Strain 1011} \\
\hline & & $1 \times 10^{2}$ & $1 \times 10^{3}$ & $1 \times 10^{4}$ & $1 \times 10^{5}$ & $1 \times 10^{8}$ & $1 \times 10^{2}$ & $1 \times 10^{3}$ \\
\hline & & \multicolumn{7}{|c|}{ Reciprocals of PD50* } \\
\hline No. 1 & 10 & - & 13 & - & $<5$ & - & 15 & $<5$ \\
\hline No. 2 & 10 & 23 & 24 & . & 13 & $<5$ & $>40$ & 8 \\
\hline No. 3 & 30 & 23 & 13 & $<10$ & . & - & - & . \\
\hline \multicolumn{9}{|l|}{$\begin{array}{l}\text { Antitoxic } \\
\text { serum }\end{array}$} \\
\hline No. 6 & 10 & . & 10 & c. 13 & 10 & c. 5 & $>13$ & 5 \\
\hline No. 7 & 8 & 8 & . & . & 8 & $<3$ & 8 & $<3$ \\
\hline No. 8 & 30 & 6 & 9 & . & . & . & . & . \\
\hline
\end{tabular}

Agglutinin titres of sera $1-3=1000-2000$. Antitoxic titres of sera $6-8=c$. 500 units. Agglutinin titres of sera $6-8=<100$. ${ }^{*}$ Each mouse received $0 \cdot 2 \mathrm{ml}$. serum intraperitoneally.

in Table 2 as the reciprocals of these doses. The antitoxic sera were diluted between 2 and 3 times during absorption accounting for the maximum PD 50 of $c .10$ for these sera in contrast to maximum PD 50 of $c .20$ for the antibacterial sera. The approximately constant PD50 against increasing doses of strain 1017, which are particularly evident for sera 6 and 7, are difficult to understand. An experimental investigation by means of brain culture counts would probably elucidate this problem. 
The partial protection by natural and absorbed antibacterial and antitoxic sera in mice against intracerebral challenge with pertussis strains 1017 and 1011

Agglutinins were absorbed from both antibacterial and antitoxic sera, and protective tests with the natural and absorbed sera gave the results in Table 3. Serum 2 was tested against one other dose of strain 1017 with similar results, and serum 7 against one other dose of both strains 1011 and 1017. From these results it seems unlikely that the agglutinin antibody contributes greatly to the protective properties of either antibacterial or antitoxic sera. This work was considered necessary since the antibacterial sera used in all the previous experiments were natural sera, while agglutinins were absorbed from the antitoxic sera.

Table 3. Fifty $\%$ end-points of protection with natural and absorbed antibacterial and antitoxic sera against intracerebral challenge with pertussis strains 1011 and 1017, compared with the agglutinin titres of these sera

\begin{tabular}{|c|c|c|}
\hline Antibacterial serum 2 & Natural & Absorbed \\
\hline $\begin{array}{l}\text { *Reciprocals of } \\
\text { PD 50 } \\
\text { Agglutinin titres }\end{array}$ & $\begin{array}{r}8 \cdot 5 \\
7 \cdot 0 \\
1000\end{array}$ & $\begin{array}{r}7 \cdot 5 \\
5 \cdot 5 \\
100\end{array}$ \\
\hline Antitoxic serum 7 & & \\
\hline $\begin{array}{l}\text { *Reciprocals of } \\
\text { PD50 } \\
\text { Agglutinin titres }\end{array}$ & $\begin{array}{l}12 \\
10 \cdot 5 \\
500\end{array}$ & $\begin{array}{r}8 \\
8 \\
100\end{array}$ \\
\hline
\end{tabular}

* PD 50 calculated from dead/groups of $6,10,8$ and 8 mice respectively. Each mouse received $\mathbf{0 . 2} \mathrm{ml}$. serum intraperitoneally.

The comparison of the partial protection in mice against a dose of virulent pertussis organisms injected intracerebrally and instilled intranasally

The results given in Table 4 show that both antibacterial and antitoxic sera protect similarly against a virulent dose of pertussis organisms whether administered by the intracerebral or intranasal route. The same protective antibodies appear to be the active factors, however the challenge culture is administered.

Table 4. Fifty $\%$ end-points of protection with an antibacterial serum and an absorbed antitoxic serum against intracerebral and intranasal challenge $10^{2} \times$ LD 50 of Haemophilus pertussis strain 1011 administered $24 \mathrm{hr}$. after serum.

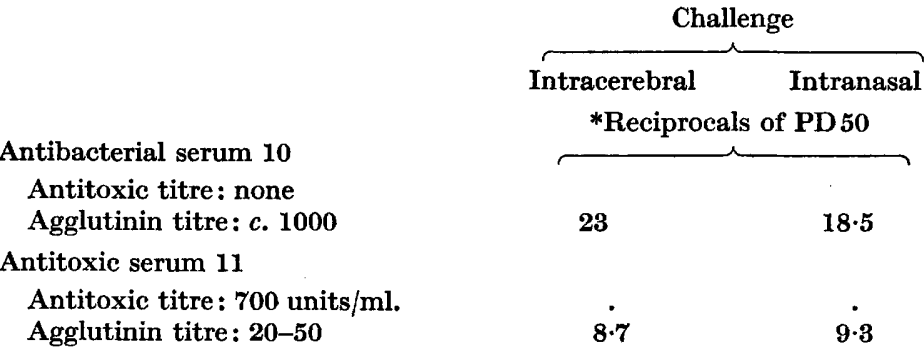

* PD 50 calculated from dead/groups of 30 and 20 mice respectively. Each mouse received $\mathbf{0 \cdot 2} \mathrm{ml}$. serum intraperitoneally. 


\section{DISCUSSION}

It is of interest that the highest average counts of pertussis organisms found in mouse brains after lethal intracerebral doses were approximately constant, in view of the results obtained by workers on anthrax. Keppie, Smith \& Stanley (1953) found that the total yield of bacilli collected from successive batches of 100 guinea-pigs dying of anthrax was remarkably constant. Keppie Smith \& Harris-Smith (1953) also found that similar total counts of anthrax organisms were found in six guinea-pigs dying of anthrax. In the present work the maximum count of pertussis organisms obtained appeared to be somewhat dependent on the strain used and slightly lower with the less virulent strain. In an investigation of the counts of pertussis organisms in the lungs of mice after instillation of a lethal and non-lethal dose of a particular virulent strain Proom (1947) found maximum counts between 7 and 14 days. Cooper (1952) with a non-lethal dose of an unspecified virulent pertussis strain found maximum count in the lung between 7 and 8 days. With the virulent pertussis strains used in the present work and under the particular experimental conditions described, it has been found that the day on which maximum count of organisms in the brain was obtained varied with the dose of organisms and with the strain used. The larger the dose of organisms the earlier the maximum count which always occurred before the seventh day.

The nature of the antigen(s) which produces protective antibodies is not known. The haemagglutinogen isolated by Masry (1952) and the capsular material described by Evans \& Adams (1952) did not produce protective antisera. Further, the results on the protection in mice by an antibacterial and an antitoxic serum after absorption of their agglutinins indicate that neither serum was only, if at all, dependent for its protective properties on the presence of agglutinin antibodies. It would be unwise to suggest how the protective antigen described by Pillemer (1950), and produced on a large scale by Pillemer, Blum \& Lepow (1954) for clinical trials, protects against challenge cultures. Evans \& Perkins (1954 $a, b, 1955)$ described an interference immunity to intracerebral invasion and this immunity has been confirmed as acting similarly against the intranasal invasion of pertussis organisms by Fisher (1955). From the point of view of practical protection against natural invasion by Haemophilus pertussis in an animal it may be immaterial which type of antigen is used to stimulate the animal, or which type of antibody is produced. Both antibacterial and antitoxic sera have been shown to protect similarly against a small number of lethal doses of strain 1011 injected intracerebrally or instilled intranasally. However, from the viewpoint of standardization of vaccines a more complete knowledge of all antigens would be advantageous.

I am grateful to Mr A. F. B. Standfast (Lister Institute, Elstree) for considerable help with the presentation of these results, and to Dr L. F. Hewitt for interest in the work. 


\section{REFERENCES}

Buss, C. I. (1935). The calculation of the dosage mortality curve. Ann. appl. Biol. 22, 134.

Brown, H. G. \& Kirwan, E. W. O.'G. (1915). Standardisation of bacterial suspensions by opacity. Indian J. med. Res. $2,763$.

Burnet, F. M. \& Trmmins, C. (1937). Experimental infection with Haemophilus pertussis in the mouse by intranasal inoculation. Brit. J. exp. Path. 18, 83.

Cohen, S. M. \& Wheeler, M. W. (1946). Pertussis vaccines produced with phase 1 cultures grown on fluid medium. Amer. J. publ. Hlth, 36, 371.

Cooper, G. N. (1952). Activity immunity in mice following the intranasal injection of sub-lethal doses of living Haemophilus pertussis. J. Path. Bact. 64, 65.

Evans, D. G. \& Adams, M. O. (1952). The inability of the capsular material of Haemophilus pertussis to produce protective antisera. J. gen. Microbiol. 7, 169.

Evans, D. G. \& MaItland, M. B. (1937). The preparation of the toxin of Haemophilus pertussis, its properties and relation to immunity. J. Path. Bact. 45, 715.

Evans, D. G. \& Perkins, F. T. (1954a) The ability of Pertussis vaccine to produce in mice specific immunity of a type not associated with antibody production. Brit. J. exp. Path. 35, 322.

Evans, D. G. \& Perkins, F. T. (1954b). Interference immunity produced by Pertussis vaccine to pertussis infection in mice. Brit. J. exp. Path. 35, 603.

Evans, D. G. \& Perkins, F. T. (1955). The production of both interference and antibody immunity by Pertussis vaccine and pertussis infection in mice. Brit. J. exp. Path. 36, 391.

Pisher, R. A. \& Yates, F. (1949). Statistical Tables for Biological, Agricultural and Medical Research. Edinburgh: Oliver and Boyd.

Fisher, S. (1955). Multiplication of Haemophilus pertussis in the mouse lung following intranasal infection. Aust. J. exp. Biol. 33, 609.

Keppie, J., Smith, H. \& Harris-Smrth, P. W. (1953). The chemical basis of the virulence of Bacillus anthracis. II. Some biological properties of bacterial products. Brit. J. exp. Path. 34, 486.

Keppie, J., Smith, H. \& Stanley, J. L. (1953). A method for collecting bacteria and their products from infections in experimental animals, with special reference to Bacillus anthracis. Brit. J. exp. Path. 34, 471.

Kendrick, P. L., Eldering, G., Dixon, M. K. \& Misner, J. (1947). Mouse protection tests in the study of Pertussis vaccine. A comparative series using the intracerebral route for challenge. Amer. J. publ. Hlth, 37, 803.

Kendrick, P. L., Updyke, E. L. \& Eldering, G. (1949). Comparison of pertussis cultures by mouse protection and virulence tests. Amer. J. publ. Hlth, 39, 179.

Linggood, F. V. \& Fenton, E. L. (1947). The production of diphtheria toxin by submerged culture in shaking flasks. Brit. J. exp. Path. 28, 354.

Masry, F. L. G. (1952). Production, extraction and purification of the haemagglutinin of Haemophilus pertussis. J. gen. Microbiol. 7, 201.

Miles, A. A. \& Mrsra, S. S. (1938). The estimation of the bactericidal power of blood. J. Hyg., Camb. 38, 732.

M.R.C. RePont (1956). Vaccination against whooping cough. A report to the whooping cough immunisation committee of the Medical Research Council and to the Medical Officers of Health for Leeds, Leyton, Manchester, Middlesex, Oxford, Poole, Tottenham, Walthamstow and Wembley. Brit. med. J. ii, 454.

Nonton, J. F. \& Dingle, J. H. (1935). Virulence tests for typhoid bacilli and antibody relationships in antityphoid sera. Amer. J. publ. Hlth, 37, 803.

Ospeck, A. G. \& Roberts, M. E. (1944). Pertussis antitoxin: its relationship and protection in actively and passively immunised mice and rabbits. J. infect. Dis. 74, 22. 
Pillemer, L. (1950). Adsorption of protective antigen of Haemophilus pertussis on human red cell stromata. Proc. Soc. exp. Biol., N.Y. 75, 704.

Pillemer, L., Blum, L. \& Lepow, P. H. (1954). Protective antigen of Haemophilus pertussis. Lancet, $\mathrm{i}, 1257$.

Proom, H. (1947). The immunological aspects of Haemophilus pertussis infection. J. Path. Bact. 59, 165.

Reed, L. J. \& Muench, H. (1938). A simple method of estimating fifty per cent end points. Amer. J. Hyg. 27, 493.

RoBerts, M. E. \& OSPECK, A. G. (1944). A pertussis toxin-antitoxin neutralisation technique. J. infect. Dis. 74, 14.

(Received 30 May 1957) 